\title{
Environmental Regulation and Corporate Cash Holdings: Evidence From China's New Environmental Protection Law
}

\author{
Chao Zhang ${ }^{1,2}$ and Jinkai Cheng ${ }^{2,3 *}$ \\ ${ }^{1}$ School of Economics, Zhejiang University, Hangzhou, China, ${ }^{2}$ Nanyang Business School, Nanyang Technological University, \\ Singapore, Singapore, ${ }^{3}$ School of Labor and Human Resources, Renmin University of China, Beijing, China
}

OPEN ACCESS

Edited by:

Umer Shahzad,

Anhui University of Finance and

Economics, China

Reviewed by:

Tomiwa Sunday Adebayo,

Cyprus International University,

Cyprus

Xin Zhao,

Anhui University of Finance and

Economics, China

Gagan Deep Sharma,

Guru Gobind Singh Indraprastha

University, India

Malik Shahzad Shabbir,

The University of Lahore, Pakistan

*Correspondence:

Jinkai Cheng

13161898822@163.com

Specialty section:

This article was submitted to

Environmental Economics and

Management,

a section of the journal

Frontiers in Environmental Science

Received: 14 December 2021

Accepted: 03 January 2022

Published: 01 February 2022

Citation:

Zhang C and Cheng J (2022)

Environmental Regulation and

Corporate Cash Holdings: Evidence

From China's New Environmental

Protection Law.

Front. Environ. Sci. 10:835301.

doi: $10.3389 /$ fenvs.2022.835301
Exploiting the 2014 Environmental Protection Law (EPL) in China as quasi-natural experiments, we adopt a difference-in-differences approach to examine the impact of environmental regulation on corporate cash holdings. We document that heavy-polluting firms increase their cash holdings 15\% more than non-heavy-polluting firms due to stringent environmental regulation. Further tests show that the heightened environmental uncertainty, the limited access to bank loans, and the decline in obtaining government subsidies for heavy-polluting firms are three plausible channels that allow environmental regulation to increase corporate cash holdings. The effects of environmental regulation on cash holdings are stronger for firms without political backgrounds and those in regions with less dependent on the secondary sector. Overall, our results offer original evidence showing how environmental regulation in emerging economies affects firms' liquidity management decisions and support the precautionary effect of cash holdings.

Keywords: environmental regulation, cash holdings, precautionary effect, quasi-natural experiment, China

\section{INTRODUCTION}

Sustainable economic development is of great importance, which has received increasing attention in the literature (Saleem et al., 2020; Anser et al., 2021b; Khan et al., 2021a; Muhammad et al., 2021; Ramzan et al., 2021; Sharma et al., 2021f; Yikun et al., 2021). Environmental degradation is one of the most pressing issues, posing serious problems to sustainable development (Adebayo et al., 2021a; Adebayo and Rjoub, 2021; Anser et al., 2021a; Arslan et al., 2021; Jun et al., 2021). The adverse impacts of environmental degradation have motivated governments to pursue a collective remedy and issue a series of environmental regulation policies to protect the environment (Adebayo et al., 2021b; Adebayo and Kirikkaleli, 2021; Kirikkaleli and Adebayo, 2021; Mughal et al., 2022). Thus, both the developing and developed countries must balance financial goals with environmental conservation to achieve sustainable development goals (Sharma et al., 2021b; Sharma et al., 2021c; Sharma et al., 2021d; Sharma and Handa, 2021). Environmental regulation has received considerable attention, but few studies investigate the economic consequences of environmental regulation on corporate-level activities, especially in corporate liquidity.

Environmental regulation is an essential means to achieve sustainable development and to deal with issues of available scarce resources as well as growing environmental pollution (Ouyang et al., 2020). Most developed and transitional countries have adopted a series of environmental policies to 
mitigate air emissions, regulate water and soil pollution, and reduce energy consumption (García-Quevedo and Jové-Llopis, 2021; Khan et al., 2021b; Villanthenkodath et al., 2021). Various previous studies have investigated the economic consequences of environmental regulation. Most indicate that environmental regulation is beneficial for national health, green growth, and social development (Li K. et al., 2019; Jin et al., 2019; Wang et al., 2019). In addition, a growing number of scholars have extended their research interests to the impact of environmental regulation on corporate-level activities. In particular, several recent studies have focused on the effects of environmental regulation on firms' innovation activities (Porter, 1991; Liu Y. et al., 2021), productivity (Wang et al., 2019; Cai and Ye, 2020), financing decisions (Caragnano et al., 2020; Ding et al., 2021), investment (Madsen, 2009; Lopez et al., 2017), and exports (Fang et al., 2019; Zhang et al., 2020). Besides, there have been several related studies in the literature about the environmental effects of COVID-19 and its potential implications. Prior studies examine the effects of COVID-19 on environmental concerns and its potential implications on business continuity (Sharma et al., 2021e; Zutshi et al., 2021). Sharma et al. (2022) find that investors would not lose on risk-adjusted returns if they chose to go green post COVID-19. This implication is that there may be immense opportunities in post-COVID world to invest in green energy instead of conventional investments and investors subsequently earn higher financial returns. Yan et al. (2021) also investigate the nexus between the international tourist arrivals, COVID-19 spread, and air quality in Hawaii. However, there are relatively few studies linking environmental regulation to corporate cash holdings, especially in China-the world's second-largest economy-after its adoption of environmental policies. In this study, we aim to fill this gap in the literature. To our knowledge, our paper is among the first to show how the stringency of environmental regulation could affect corporate cash holdings, especially in a developing country.

In this study, we investigate the causal effect on corporate cash holding behaviors of stringent environmental regulation measures using, China's Environmental Protection Law (EPL) amended and officially passed in April 2014, which delivered an exogenous shock to the level of environmental regulation in the country. China provides a unique quasi-natural experimental setting for testing the impact of environmental policies. First, China's rapid economic development over the past 4 decades has come at the expense of severe environmental pollution ${ }^{1}$ and excessive resource consumption (Zheng and Kahn, 2017; Li K. et al., 2019). As a result, the revised version of EPL, considered as the "strictest" environmental protection law in China (Liu Y. et al., 2021), plays a more crucial role in protecting the environment. This unique exogenous regulatory shock allows us to examine the impact of stricter environmental regulation on corporate cash holdings and identify the causal relationship between them. Second, heavy-polluting industries are affected

${ }^{1}$ China not only is the world's largest greenhouse gas emitter, but also fails to meet acceptable international health standards, such as the average PM2.5 concentrations amounted to 4.3 times the WHO guideline (Li K. et al., 2019). more by the new EPL than other industries, and thus firms in heavy-polluting industries can be selected as the treatment group and non-heavy-polluting industries as the control group. Therefore, the variations across industries are useful for capturing the heterogeneous effects of the introduction of the new EPL on the institutional environment and corporate behaviors. Third, the new EPL is unlikely to be triggered by corporate cash policy, thus it is an exogenous event to firms' cash decision making.

Existing studies suggest that the effects of environmental regulation on corporate cash holdings can be governed by two competing hypotheses. The precautionary motive hypothesis predicts a positive impact of environmental regulation on corporate cash holdings. The environment is ever-changing, uncertain, and unpredictable (Sharma et al., 2021a). Stringent environment regulation induces heightened environmental uncertainty (Lanoie et al., 2008) by enhancing the heavypolluting firms' environmental risks (Falk and Wee, 2015; Liu X. et al., 2021), making debt financing more difficult and costly (Caragnano et al., 2020; Pizzutilo et al., 2020; Ding et al., 2021). In addition, to achieve the social goal of sustainable development, non-heavy-polluting industries such as new energy industries, typically receive more subsidies (Qiao and Fei, 2022). The limited access to bank loans and government subsidies brings about severe financial constraints for heavy-polluting firms. Thus, the increase in heavy-polluting firms' environmental uncertainty and financial constraints stemming from the new EPL, implies an increment in the level of cash holdings for higher levels of hedging needs (Opler et al., 1999; Davydova and Sokolov, 2014; Magerakis and Habib, 2021).

In contrast, environmental regulation can decrease corporate cash holdings. There is a negative association between capital expenditures and cash balance (Opler et al., 1999; Jebran et al., 2019). The stringency of environmental regulation encourages firms to enlarge their green investment (Kesidou and Demirel, 2012; Liao and Shi, 2018), R\&D investment (Testa et al., 2011), and colossal investment equipment, increasing capital expenditures. Taken together, higher capital expenditures caused by the new EPL lead heavy-polluting firms to hold less cash. As theories offer mixed guidance, the question of how environmental regulation affects cash holdings decisions is, therefore, an empirical one.

This paper attempts to answer this question using a sample of Chinese A-share listed companies from 2010 to 2018. Our findings support the precautionary motive hypothesis. We find that environmental regulation has a significant positive effect on heavy-polluting firms' cash holdings and the effects of stringent environmental regulation on cash holdings are sustainable. On average, the new EPL brings about an increase in the level of cash holdings by almost $15 \%$, compared with non-heavy-polluting firms. Moreover, the relationship between environmental regulation and corporate cash holdings is more pronounced in heavy-polluting firms without political backgrounds and those in regions with less dependent on the secondary sector. Collectively, our results suggest that environmental regulation not only increases the environmental uncertainty for heavy-polluting firms but also disrupts firms' access to bank loans and 
government subsidies, which heightens their liquidity constraints and the need for cash holding. Because holding cash is costly for firms, this result suggests that a hidden cost faced by heavypolluting firms increases after the promulgation of the new EPL. Thus, while developing environmental rules, governments should take into consideration corporate liquidity.

This paper contributes to the literature in the following ways. First, we supplement the strand in the literature concerned with the impact of environmental regulation on corporate-level activities (e.g., Porter, 1991; Jaffe and Palmer, 1997; Galloway and Johnson, 2016; Shi and Xu, 2018). Compared with settings in other studies, our quasi-natural experiments help alleviate the endogeneity concerns by treating the new EPL as an exogenous shock to the level of environmental regulation across industries and provide causal evidence of the impact of environmental regulation on corporate cash holdings. Second, we add to the literature on the determinants of corporate cash holdings (e.g., Opler et al., 1999; Chang et al., 2021; Lin et al., 2021). To our knowledge, our paper is among the first to show how the stringency of environmental regulation could affect corporate cash holdings, especially in a developing country. Further, we explore the internal mechanisms of the regulatory effect on corporate cash holdings, providing supportive evidence for the precautionary motive. Third, our paper is related to a growing number of studies that take advantage of the new EPL amended and officially passed in April 2014 in China to investigate and understand the impact of environmental regulation on green innovation (Liu Y. et al., 2021), total factor productivity (Cai and Ye, 2020), and audit prices (Liu X. et al., 2021).

The rest of this paper is structured as follows. Section 2 provides the institutional background and hypothesis development. Section 3 discusses the sample and research design. Section 4 shows the main empirical results and robustness checks. Section 5 discusses the economic channels. Section 6 provides the additional analyses. Section 7 concludes the paper.

\section{INSTITUTIONAL BACKGROUND AND HYPOTHESIS DEVELOPMENT}

\subsection{Institutional Background}

An earlier version of the Environmental Protection Law implemented in 1989 was of great importance in environmental protection. Over the 2 decades during which the $1989 \mathrm{EPL}$ was issued, there was a huge change in the Chinese economy and society. However, over time, the 1989 EPL began to lag behind the actual needs of society and severely restricted effective environmental protection. In 2006, the environmental performance review of China, released by the Organization for Economic Co-operation and Development (OECD), noted that the effectiveness and efficiency of its existing environmental efforts were inadequate due to the shortfalls in the implementation of environmental policies. Thus, the new EPL was approved in April 2014, which was deemed as the most stringent Environmental Protection Law to date in China.
The new EPL highlights at least three aspects (Falk and Wee, 2015). First, the new EPL strengthens supervision and penalties for polluting firms. According to Article 59 of the new EPL, fines, and penalties of pollutants, including daily fines, grow dramatically. Second, the new EPL increases the accountability of government officials. According to Article 68 of the new EPL, local officials are required to resign in case of eight situations, such as covering up environmental violations, falsifying monitoring data, and failing to disclose environmental information. Third, the firms' environmental violations can be penalized on individuals such as the managers of firms by administrative detention, which has enhanced the deterrent effect. Overall, the new EPL brings about stringent environmental regulation and higher regulatory costs for heavy-polluting firms.

\subsection{Hypothesis Development}

Environmental regulation is among the most important institutional policies in China, which affects the specific behavior of heavy-polluting firms (Liu Y. et al., 2021). It is thus logical to expect that environmental regulation affects corporate cash holdings. We propose that the effect of the enactment of the new EPL on corporate cash holdings may be multi-dimensional.

The new EPL has the potential to increase the level of heavypolluting firms' cash holdings for several reasons. First, the stringency of environmental regulation results in heightened uncertainty (Lanoie et al., 2008), thus positively affecting corporate cash holdings (Magerakis and Habib, 2021). Stringent environmental regulation induced by the new EPL increases the possibility of heavy-polluting firms being suspended or even forced to close when they fail to comply with environmental protection laws and regulations. This not only increases the uncertainty of heavy-polluting firms' production and operation (Liu et al., 2018) but also enhances the heavy-polluting firms' legal risks of pollutants with more potential lawsuits (Falk and Wee, 2015; Liu X. et al., 2021), thereby causing firms to reserve more cash to prevent and resist external liquidity risk timely and effectively in uncertain times (Han and Qiu, 2007). On the other hand, heightened uncertainty increases financial constraints, thereby, forcing firms to hoard cash to buffer them against contingencies (Campello et al., 2010). Firms hoard cash to diminish the possibility of distress, sustain operational efficiency, and enhance profitability (Han and Qiu, 2007; Phan et al., 2019; Magerakis and Habib, 2021). According to the precautionary motive, heavy-polluting firms are more likely to stockpile cash in response to heightened environmental uncertainty ${ }^{2}$ stemming from environmental regulation. That is, following the precautionary motive, we expect heavy-polluting firms will

${ }^{2}$ The concept of environmental uncertainty is defined as the variability of change that characterizes environmental activities relevant to a firm's operations, and government regulation is one of the important factors affecting environmental uncertainty (Huang et al., 2017; Magerakis and Habib, 2021). 
hold more cash when operating in an environment of high uncertainty arising from the new EPL.

Second, inferences drawn from prior studies suggest that environmental regulation increases heavy-polluting firms' environmental liabilities and environmental risks (Schneider, 2008), making debt financing more difficult and costly (Caragnano et al., 2020; Pizzutilo et al., 2020; Ding et al., 2021). In the Chinese capital market, bank loans are the main source of external finance for corporations, due to the immature stock and bond market (Cull and Xu, 2000; Shen et al., 2015). In this sense, firms in China are mostly bank-dependent and the borrowings of most firms are supported by bank loans (Firth et al., 2012; Liu et al., 2018). The new EPL disrupts heavypolluting firms' access to bank loans because banks which include an appraisal of environmental aspects in the credit risk assessments of their lending decisions (Aintablian et al., 2007), have taken over mortgaged assets that may have lost commercial value because of environmental pollutants or the need for an environmental clean-up by a defaulting borrower (Thompson and Cowton, 2004). The precautionary motive theory states that bank debt and cash holdings are negatively related (Ferreira and Vilela, 2004; Ozkan and Ozkan, 2004). Because of higher external financing costs after the promulgation of the new EPL, heavy-polluting firms decrease their debt-financing and increase internal cash reserves (Gilchrist et al., 2014; Lee and Wang, 2021). Thus, the precautionary motive for holding cash implies that heavy-polluting firms tend to hoard more cash during periods of lower access to bank loans stemming from the enactment of the new EPL.

Third, heavy-polluting firms receive fewer subsidies because they are not expected to pursue social goals such as environmental protection (Lee, 2001; O'Connor et al., 2006), thus positively affecting corporate cash holdings by exacerbating firms' financial constraints (Girma et al., 2007; Davydova and Sokolov, 2014). Stricter environmental regulation highlights the importance of sustainable development (Falk and Wee, 2015; Li Y. et al., 2019), so the governments encourage the development of non-heavypolluting industries, such as new energy industries, as part of their energy conservation and emission reduction policies (Qiao and Fei, 2022). To achieve such social policy objectives, subsidies are a policy lever through which governments direct financial resources to favored industries (Brealey et al., 2018; Deng et al., 2021), and thus non-heavy-polluting firms typically receive more subsidies than heavy-polluting firms. Existing studies have provided evidence that subsidies can alleviate financing constraints. In addition, based on signal theory (Spence, 1974), government subsidies serve as a market signal for financial institutions including banks, which can help financial institutions to identify firms' potential, leading to more funding allocated to those firms. Therefore, heavypolluting firms receiving fewer subsidies are associated with severe financial constraints, and they are likely to hoard more cash to better deal with the shocks generated by the new EPL.

Considering the above, we propose the following hypotheses:

H1a: Environmental regulation increases corporate cash holdings.
H2: Environmental regulation increases corporate cash holdings through heightened environmental uncertainty.

H3: Environmental regulation increases corporate cash holdings through limited access to banks loans.

H4: Environmental regulation increases corporate cash holdings through limited access to government subsidies.

However, environmental regulation may induce heavypolluting firms to save less cash for several aspects. Prior studies show that capital expenditures cut down a firm's cash balance (Opler et al., 1999; Jebran et al., 2019). Kim et al. (2011) also argue that capital expenditures increase the assets, used as collateral for borrowing, which could reduce the need of hoarding cash. That is, there is a negative relationship between capital expenditure and cash holdings. First, local governments' enforcement of stricter environmental regulation encourages firms to increase their green investment (Leiter et al., 2009; Kesidou and Demirel, 2012; Liao and Shi, 2018), which may cause firms to dilute cash reserves. Second, the Porter hypothesis argues that environmental regulation has a positive effect on technological innovation activities (Porter, 1991; Porter and Van der Linde, 1995). The stringency of environmental regulation provides a positive impetus for $\mathrm{R} \& \mathrm{D}$ investment and innovative products (Testa et al., 2011), which are likely to lead to the reduction in the level of cash holdings. Third, heavy-polluting firms have higher environmental regulation costs under environmental regulation policies, such as colossal investment equipment, high replacement costs, or high cost of equipment modification to reduce pollution, which results in higher demand for funds (Ouyang et al., 2020), thus promoting firms to reduce cash to meet the necessary needs of capital expenditures. Therefore, environmental regulation causes an additional expenditure of heavy-polluting firms' pollution control costs, and occupies a large amount of technology innovation funds, leading to the decrease in cash holdings.

Considering these arguments, we propose an alternative hypothesis:

H1b: Environmental regulation decreases corporate cash holdings

\section{SAMPLE AND RESEARCH DESIGN}

\subsection{Sample and Data Sources}

Our initial sample consists of all Chinese A-share listed firms from 2010 to 2018. Following Cai et al. (2021), our sample begins in 2010 to mitigate the negative shocks of the 2008 global financial crisis and its impact on corporate cash holdings. Our sample ends in 2018 so that we have a symmetry window of 4 years before and after the promulgation of the new EPL in 2014. The firm-level data used in this paper is obtained from CSMAR/WIND, a dataset similar to (and, in fact, fashioned on) the CRSP and COMPUSTAT databases. We further exclude special firms from our sample: 1) firms belonging to the financial industry and real estate industry; 2) firms designated for special treatment (ST) or particular transfer (PT) by the regulatory authorities; 3 ) firms with missing variables. 
TABLE 1 | Variable definitions.

\begin{tabular}{|c|c|}
\hline Variables & Definitions \\
\hline Cash1 & The ratio of cash and cash equivalents to total assets \\
\hline Cash2 & The ratio of cash and marketable securities to total assets \\
\hline Treat & A dummy variable that equals 1 for polluting firms and 0 for other firms \\
\hline Post & An indicator variable equal to 1 for the period after the promulgation of the new EPL in 2014 , and 0 otherwise \\
\hline Size & The natural logarithm of total assets \\
\hline Lev & The ratio of total liabilities to total assets net of total liabilities \\
\hline CapEx & The ratio of capital expenditures to total assets \\
\hline Growth & The growth rate of total assets \\
\hline ROE & Return on equity \\
\hline CF & The ratio of operating cash flow to total assets \\
\hline$T B Q$ & The natural logarithm of market value of assets divided by the book value of assets (Bartlett and Partnoy, 2020) \\
\hline Dividend & A dummy variable that equals 1 if a firm pays cash dividends, and 0 otherwise \\
\hline SOE & A dummy variable that equals 1 if a firm is ultimately controlled by governments, and 0 otherwise \\
\hline
\end{tabular}

The final sample contains 19,959 firm-year observations. To mitigate the effects of outliers, all continuous variables are winsorized by year at the $1 \%$ level on each tail.

\section{METHODOLOGY}

We use a difference-in-differences design with firm and year fixed effects and our main model is as follows:

$$
\operatorname{Cash}_{i, t}=\alpha+\beta\left(\text { Treat }_{i, t} \times \text { Post }_{i, t}\right)+\vartheta X_{i, t}+\gamma_{i}+\delta_{t}+\varepsilon_{i, t}
$$

where $\mathrm{i}$ represents the firm, $\mathrm{t}$ represents the year, and the dependent variable Cash denotes the cash holdings level. Following the prior literature (e.g., Hasan et al., 2021; Lin et al., 2021; Seo and Han, 2021), we use two continuous variables to measure cash holdings. The first measure (Cash1) is defined as the ratio of cash and cash equivalents to total assets. The second measure (Cash2) is defined as the ratio of cash and marketable securities to total assets. Treat is a dummy variable that equals one for heavy-polluting firms and 0 for other firms. As for the classification of heavy-polluting firms, the 14 polluting industries were selected based on the "List of classified management of environmental protection inspection for polluting industries" issued by the Ministry of Environmental Protection of China in July 2008 (http://www.gov.cn/gzdt/200807/07/content_1038083.htm). They include thermal power, iron, and steel, coal, metallurgy, mining, chemical industry, petrochemicals, building materials, papermaking, brewing, pharmaceutical, textile, leather, and fermentation. Post is an indicator variable equal to one for the period after the promulgation of the new EPL in 2014, and 0 otherwise.

The control variables employed in the regressions are firmspecific controls motivated by Opler et al. (1999), Ozkan and Ozkan (2004), Harford et al. (2008), Cai et al. (2021), Xiong et al. (2021), and Nyborg and Wang (2021). They include firm size (Size), the leverage ratio (Lev), capital expenditure (CapEx), firm growth (Growth), Return on equity ( $R O E$ ), operating cash flow $(C F)$, Tobin's $\mathrm{Q}(T B Q)$, the dividend dummy (Dividend), state ownership (SOE). Table 1 provides the definitions of variables used in the analysis.

\begin{tabular}{|c|c|c|c|c|c|c|}
\hline Variable & $\mathbf{N}$ & Mean & SD & P25 & Median & P75 \\
\hline Cash1 & 19,959 & 0.166 & 0.132 & 0.073 & 0.127 & 0.217 \\
\hline Cash2 & 19,959 & 0.188 & 0.136 & 0.093 & 0.151 & 0.245 \\
\hline Treat & 19,959 & 0.382 & 0.486 & 0 & 0 & 1 \\
\hline Post & 19,959 & 0.527 & 0.499 & 0 & 1 & 1 \\
\hline Treat $\times$ Post & 19,959 & 0.233 & 0.423 & 0 & 0 & 0 \\
\hline Size & 19,959 & 22.060 & 1.259 & 21.160 & 21.900 & 22.790 \\
\hline Lev & 19,959 & 1.078 & 1.216 & 0.337 & 0.702 & 1.361 \\
\hline CapEx & 19,959 & 0.053 & 0.049 & 0.017 & 0.039 & 0.074 \\
\hline Growth & 19,959 & 0.215 & 0.491 & 0.020 & 0.103 & 0.235 \\
\hline ROE & 19,959 & 0.065 & 0.105 & 0.030 & 0.068 & 0.110 \\
\hline CF & 19,959 & 0.043 & 0.070 & 0.005 & 0.042 & 0.084 \\
\hline$T B Q$ & 19,959 & 0.461 & 0.831 & -0.081 & 0.490 & 1.026 \\
\hline Dividend & 19,959 & 0.750 & 0.433 & 0 & 1 & 1 \\
\hline SOE & 19,959 & 0.380 & 0.485 & 0 & 0 & 1 \\
\hline
\end{tabular}

\subsection{Descriptive Statistics}

Table 2 presents the descriptive statistics of the main variables used in the regression analysis. The mean and median of Cash 1 (Cash2) are $0.166(0.188)$ and $0.127(0.151)$, respectively, indicating that many public firms in China have large cash holdings. The average value of Treat is 0.382 , indicating that heavy-polluting firms account for around $38.2 \%$ of the entire sample. For an average firm in our sample, the firm size is 22.060 . The summary results of the other controls broadly align with previous studies (e.g., Cai et al., 2021; Liu X. et al., 2021).

\section{MAIN EMPIRICAL RESULTS}

\subsection{Baseline Results}

We begin by examining the association between environmental regulation and corporate cash holdings by applying model (1). Table 3 presents the baseline results of the difference-indifferences model. A significantly positive coefficient on Treat $\times$ Post indicates an increase in corporate cash holdings. We use two regression specifications. Columns 1) and 2) do not include control variables, while columns 3 ) and 4) include control variables. Columns 1) and 3) in Table 3 present the 
TABLE 3 | Environmental regulation and corporate cash holdings.

\begin{tabular}{|c|c|c|c|c|}
\hline \multirow[t]{2}{*}{ Dependent variable $=$} & \multirow{2}{*}{$\frac{\text { Cash1 }}{\text { (1) }}$} & \multirow{2}{*}{$\frac{\text { Cash2 }}{\text { (2) }}$} & \multirow{2}{*}{$\frac{\text { Cash1 }}{\text { (3) }}$} & \multirow{2}{*}{$\frac{\text { Cash2 }}{(4)}$} \\
\hline & & & & \\
\hline Treat $\times$ Post & $\begin{array}{c}0.032^{\star \star \star} \\
(0.011)\end{array}$ & $\begin{array}{c}0.036^{\star \star \star} \\
(0.012)\end{array}$ & $\begin{array}{c}0.025^{\star \star \star} \\
(0.009)\end{array}$ & $\begin{array}{c}0.029^{\star \star \star} \\
(0.011)\end{array}$ \\
\hline Size & & & $\begin{array}{c}-0.020^{\star \star \star} \\
(0.005)\end{array}$ & $\begin{array}{c}-0.019^{\star \star \star} \\
(0.006)\end{array}$ \\
\hline Lev & & & $\begin{array}{c}-0.015^{\star \star \star} \\
(0.002)\end{array}$ & $\begin{array}{c}-0.013^{\star \star \star} \\
(0.002)\end{array}$ \\
\hline CapEx & & & $\begin{array}{c}-0.103^{\star \star \star} \\
(0.028)\end{array}$ & $\begin{array}{c}-0.134^{\star \star \star} \\
(0.031)\end{array}$ \\
\hline Growth & & & $\begin{array}{c}0.023^{\star \star \star} \\
(0.003)\end{array}$ & $\begin{array}{c}0.023^{\star \star \star} \\
(0.003)\end{array}$ \\
\hline$R O E$ & & & $\begin{array}{l}-0.013 \\
(0.009)\end{array}$ & $\begin{array}{l}-0.005 \\
(0.010)\end{array}$ \\
\hline$C F$ & & & $\begin{array}{c}0.194^{\star \star \star} \\
(0.021)\end{array}$ & $\begin{array}{c}0.197^{\star \star \star} \\
(0.021)\end{array}$ \\
\hline$T B Q$ & & & $\begin{array}{c}0.012^{\star \star \star} \\
(0.004)\end{array}$ & $\begin{array}{l}0.008^{\star} \\
(0.005)\end{array}$ \\
\hline Dividend & & & $\begin{array}{c}0.025^{\star \star \star} \\
(0.002)\end{array}$ & $\begin{array}{c}0.026^{\star \star \star} \\
(0.002)\end{array}$ \\
\hline SOE & & & $\begin{array}{l}-0.013 \\
(0.009)\end{array}$ & $\begin{array}{l}-0.012 \\
(0.009)\end{array}$ \\
\hline Firm fixed effects & YES & YES & YES & YES \\
\hline Year fixed effects & YES & YES & YES & YES \\
\hline $\mathrm{N}$ & 19,573 & 19,573 & 19,573 & 19,573 \\
\hline$R^{2}$ & 0.612 & 0.607 & 0.642 & 0.632 \\
\hline
\end{tabular}

Standard errors clustered at the industry level are reported in parentheses. * **, and *** denote significance at the level of 10,5, and 1\%, respectively.

results for when the dependent variable is Cash1, and Columns 2) and 4) in Table 3 present the results for when the dependent variable is Cash2. Across all four columns, the estimated coefficients of the interaction term (Treat $\times$ Post) are 0.032 , $0.036,0.025$, and 0.029 , respectively, and all are significant at the $1 \%$ level, suggesting that relative to non-heavy-polluting firms, heavy-polluting firms significantly increase their cash holdings after the promulgation of the new EPL.

In addition to its statistical significance, these results are also economically significant. Specifically, the results in column 3) [column (4)] show that heavy-polluting firms exhibit a 2.5 (2.9) percentage point increase in cash holdings in the post-regulation period, which translates to a $15.1 \%$ (calculated as $2.5 \% / 16.6 \%$ ) [15.4\% (calculated as $2.9 \% / 18.8 \%)]$ increase in the mean $(16.6 \%$, Cash 1$)((18.8 \%$, Cash2)) cash holdings of the sample firms. These results support $\mathrm{Hla}$, confirming the precautionary motives, and indicating that heavy-polluting firms are more likely to stockpile cash in response to heightened environmental uncertainty, limited access to banks loans, and government subsidies stemming from environmental regulation.

\subsection{The Parallel Trend and Dynamic Effects of Environmental Regulation on Corporate Cash Holdings}

Parallel trends assumption as a precondition for the use of the difference-in-differences model, the treatment and control groups must exhibit similar trends in cash holdings before the promulgation of the new EPL. To test this assumption, we replace the variable Post with eight indicator variables: Year 2011 ,

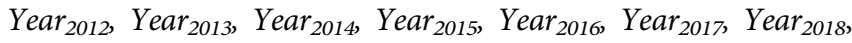
where $Y^{e a r} r_{j}$ is an indicator variable equal to one if the firm-year is in year $j$, and 0 otherwise. We interact these dummy variables with the variable Treat and rerun the regressions using model (1). If the coefficient of Treat Year $_{j}(\mathrm{j}<2014)$ is not significant, we can conclude that there is no pre-regulation difference in cash holdings between the treatment and control samples (i.e., the parallel trend assumption holds). If environmental regulation induced higher cash holdings during the period studied, the coefficients of Treat $\times$ Year $_{j}(\mathrm{j}$ $>$ 2014) should be significantly positive.

The empirical results for the dynamics of cash holdings are reported in Table 4 . The coefficients of Treat $\times$ Year $_{2011}$, Treat $\times$ Year $_{2012}$, and Treat $\times$ Year $_{2013}$ are small and statistically insignificant. The coefficients of Treat $\times$ Year $_{2014}$ are positive but statistically indistinguishable from zero, perhaps because it takes time for the environmental regulation to make a difference. As expected, the coefficients of Treat $\times$ Year $_{2015}$, Treat $\times$ Year $_{2016}$, Treat $\times$ Year $_{2017}$, and Treat $\times$ Year $_{2018}$ are positive and significant at least at the $5 \%$ level. Overall, the results of the parallel trend tests suggest that our sample satisfies the parallel trend assumption that heavy-polluting firms and non-heavypolluting firms exhibit similar cash-holding behavior before the promulgation of the new EPL; significant differences in cash holdings between the two groups only occur after the enactment of the new EPL.

\subsection{Confounding Events}

To alleviate the concern of the influence of confounding factors that may challenge our main results, we conduct additional

TABLE 4 | The parallel trend and dynamic effects of environmental regulation on corporate cash holdings.

\begin{tabular}{|c|c|c|c|c|}
\hline \multirow[t]{2}{*}{ Dependent variable = } & \multirow{2}{*}{$\frac{\text { Cash1 }}{(1)}$} & \multirow{2}{*}{$\frac{\text { Cash2 }}{(2)}$} & \multirow{2}{*}{$\frac{\text { Cash1 }}{(3)}$} & \multirow{2}{*}{$\frac{\text { Cash2 }}{\text { (4) }}$} \\
\hline & & & & \\
\hline \multirow[t]{2}{*}{ Treat Year $_{2011}$} & -0.007 & -0.005 & -0.009 & -0.007 \\
\hline & (0.007) & $(0.008)$ & $(0.007)$ & (0.008) \\
\hline \multirow[t]{2}{*}{ Treat Year $_{2012}$} & 0.002 & 0.002 & -0.001 & -0.000 \\
\hline & $(0.007)$ & (0.008) & $(0.007)$ & (0.008) \\
\hline \multirow[t]{2}{*}{ Treat Year $_{2013}$} & 0.001 & 0.000 & -0.001 & -0.001 \\
\hline & (0.008) & (0.008) & (0.008) & (0.008) \\
\hline \multirow[t]{2}{*}{ Treat Year $_{2014}$} & 0.013 & 0.013 & 0.010 & 0.010 \\
\hline & (0.009) & (0.009) & $(0.009)$ & (0.009) \\
\hline \multirow[t]{2}{*}{ Treat Year $_{2015}$} & $0.024^{\star \star}$ & $0.029^{\star \star}$ & $0.023^{\star \star}$ & $0.027^{\star *}$ \\
\hline & (0.010) & (0.011) & (0.010) & $(0.011)$ \\
\hline \multirow[t]{2}{*}{ Treat Year $_{2016}$} & $0.033^{\star \star \star}$ & $0.037^{\star \star \star}$ & $0.024^{\star \star \star}$ & $0.029^{\star * *}$ \\
\hline & (0.010) & (0.011) & (0.009) & (0.010) \\
\hline \multirow[t]{2}{*}{ Treat Year $_{2017}$} & $0.040^{\star \star \star}$ & $0.044^{\star \star \star}$ & $0.028^{\star *}$ & $0.033^{\star \star *}$ \\
\hline & (0.013) & (0.014) & $(0.011)$ & (0.012) \\
\hline \multirow[t]{2}{*}{ Treat Year $_{2018}$} & $0.049^{\star \star \star}$ & $0.054^{\star \star \star}$ & $0.032^{\star \star}$ & $0.038^{\star \star *}$ \\
\hline & (0.014) & (0.015) & $(0.012)$ & (0.013) \\
\hline Control variables & NO & NO & YES & YES \\
\hline Firm fixed effects & YES & YES & YES & YES \\
\hline Year fixed effects & YES & YES & YES & YES \\
\hline $\mathrm{N}$ & 19,573 & 19,573 & 19,573 & 19,573 \\
\hline$R^{2}$ & 0.613 & 0.608 & 0.642 & 0.633 \\
\hline
\end{tabular}

Standard errors clustered at the industry level are reported in parentheses. *, **, and ${ }^{* * *}$ denote significance at the level of 10, 5, and 1\%, respectively. 
TABLE 5 | Controlling for other policy reforms.

\begin{tabular}{|c|c|c|c|c|c|c|}
\hline \multirow[t]{2}{*}{ Dependent variable $=$} & Cash1 & Cash2 & Cash1 & Cash2 & Cash1 & Cash2 \\
\hline & (1) & (2) & (3) & (4) & (5) & (6) \\
\hline Treat $\times$ Post & $0.024^{\star \star}$ & $0.028^{\star \star}$ & $0.025^{\star \star \star}$ & $0.029^{\star \star \star}$ & $0.020^{\star \star}$ & $0.021^{\star \star}$ \\
\hline GCG & $\begin{array}{c}0.003 \\
(0.006)\end{array}$ & $\begin{array}{c}0.002 \\
(0.006)\end{array}$ & & & & \\
\hline$P L S$ & & & $\begin{array}{c}0.001 \\
(0.004)\end{array}$ & $\begin{array}{c}0.002 \\
(0.004)\end{array}$ & & \\
\hline Firm fixed effects & YES & YES & YES & YES & YES & YES \\
\hline Year fixed effects & YES & YES & YES & YES & YES & YES \\
\hline $\mathrm{N}$ & 19,573 & 19,573 & 19,573 & 19,573 & 19,573 & 19,573 \\
\hline$R^{2}$ & 0.642 & 0.632 & 0.642 & 0.632 & 0.651 & 0.643 \\
\hline
\end{tabular}

Standard errors clustered at the industry level are reported in parentheses. *, **, and ${ }^{* *}$ denote significance at the level of 10, 5, and 1\%, respectively.

analyses to investigate two concurrent events around the new EPL. Specifically, to control for the two ongoing policy reforms (Green Credit Guidelines and the Reform of Pollution Levy Standards), we add two control variables to the regression. First, in 2012, the China Banking Regulatory Commission implemented the Green Credit Guidelines (GCG) to curb industrial pollution by financially penalizing polluters. It requires commercial banks to restrict lending to polluting firms and provide financial supports for environmentally friendly firms. Referring to Wen et al. (2021), who studied the treatment effect of policy shock of GCG on firm performance, in columns 1) and 2) of Table 5, we add to the regression an additional control, GCG. The coefficients of GCG are found to be statistically insignificant, suggesting a little effect on our main results. Moreover, the coefficients of our regressor of interest (Treat $\times$ Post) remain negative and statistically significant. Second, since 2007, each provincial government in China has determined whether raise $\mathrm{SO}_{2}$ levy standards, which may affect cash-holding behavior. In columns 3) and 4) of Table 5, we add an additional variable PLS to capture the effects of the staggered passage of the Reform of Pollution Levy Standards on firm performance. The coefficients of $P L S$ are close to zero and statistically insignificant, while the coefficients on Treat $\times$ Post are consistently significant, indicating our baseline result in Table 3 is robust when controlling for the confounding events. Finally, unobservable provincial trends can be an important source of endogeneities. To rule out this possibility, we include province-by-year fixed effects for all major regressions. The regression results tabulated in columns 5) and 6) of Table 5 indicate that the effects of environmental regulation are qualitatively similar to the baseline results.

\subsection{Robustness Checks}

In this section, we check the reliability and validity of our results by carrying out a battery of robustness tests. First, as a sensitivity analysis, we re-run the regression model 1) using alternative measures of cash holdings and report the results in columns 1) and 2) of Table 6. We define Cash3 and Cash4 as the ratio of cash and cash equivalents to net assets (total assets net of cash and cash equivalents) and the ratio of cash and marketable securities to net assets (total assets net of cash and marketable securities), respectively. Columns 1) to 2) show that the relation between environmental regulation and cash holdings remains positive and significantly significant when alternative measures of cash holdings (e.g., Cash3 and Cash4) are used in the analysis, indicating that the findings from this sensitivity analysis corroborate our baseline results reported in Table 3 .

Second, to further mitigate the concern that treatment and control firms could be systematically different and thus potentially influence the decisions of holding cash, we use the propensity score matching (PSM) method, proposed by Rosenbaum and Rubin (1983), to construct matched control sample. Firm size (Size), the leverage ratio (Lev), capital expenditure (CapEx), firm growth (Growth), Return on equity $(R O E)$, operating cash flow $(C F)$, Tobin's $\mathrm{Q}(T B Q)$, the dividend dummy (Dividend) and state ownership ( $S O E)$ as covariates are helpful to select samples of control group which has similar characteristics with treatment group. Thus, these variables are used as matching variables. Then, we use the 1:4 nearest neighbor matching method (Abadie et al., 2004). The regression results of the PSM-DID method are reported in columns 1) and 2) of Table $5^{3}$. The coefficients on Treat $\times$ Post are positive and highly significant irrespective of the measures of cash holdings, suggesting that polluting firms hold significantly more cash after the promulgation of the new EPL.

Finally, we conduct two placebo tests to investigate the possibility that our results are purely driven by chance or the overall time trend. In the first placebo test, following Chen et al. (2021), we draw a random sample of 1,244 firms (the same number of the treated firms) as treatment firms over the sample period and the dummy variable Post is consistent with our baseline regression. Based on these "pseudo" treatment and control groups, we rerun the regressions using model 1) and save the coefficients on Treat $\times$ Post. We then repeat this procedure 1,000 times. Panel A of Figure 1 plots the empirical

\footnotetext{
${ }^{3}$ In untabulated tests, we find that there is no significant difference in covariates between the heavy-polluting firms and the control firms, supporting the validity of the PSM approach.
} 
TABLE 6 | A series of robustness tests.

\begin{tabular}{|c|c|c|c|c|c|c|}
\hline \multirow[t]{3}{*}{ Dependent variable = } & Cash3 & Cash4 & Cash1 & Cash2 & Cash1 & Cash2 \\
\hline & \multicolumn{2}{|c|}{ Alternative variables } & \multicolumn{2}{|c|}{ PSM-DID } & \multicolumn{2}{|c|}{ Placebo results } \\
\hline & (1) & (2) & (3) & (4) & (5) & (6) \\
\hline Treat×Post & $\begin{array}{l}0.074^{\star *} \\
(0.028)\end{array}$ & $\begin{array}{l}0.083^{\star \star} \\
(0.033)\end{array}$ & $\begin{array}{l}0.020^{\star *} \\
(0.010)\end{array}$ & $\begin{array}{l}0.023^{\star \star} \\
(0.011)\end{array}$ & & \\
\hline Treat $\times$ Post $_{2010}$ & & & & & $\begin{array}{l}-0.000 \\
(0.006)\end{array}$ & $\begin{array}{c}0.000 \\
(0.006)\end{array}$ \\
\hline Control variables & YES & YES & YES & YES & YES & YES \\
\hline Firm fixed effects & YES & YES & YES & YES & YES & YES \\
\hline Year fixed effects & YES & YES & YES & YES & YES & YES \\
\hline $\mathrm{N}$ & 19,573 & 19,573 & 11,198 & 11,198 & 10,928 & 10,929 \\
\hline$R^{2}$ & 0.557 & 0.566 & 0.669 & 0.663 & 0.793 & 0.793 \\
\hline
\end{tabular}

Standard errors clustered at the industry level are reported in parentheses. *, **, and ${ }^{* * *}$ denote significance at the level of 10, 5, and 1\%, respectively.

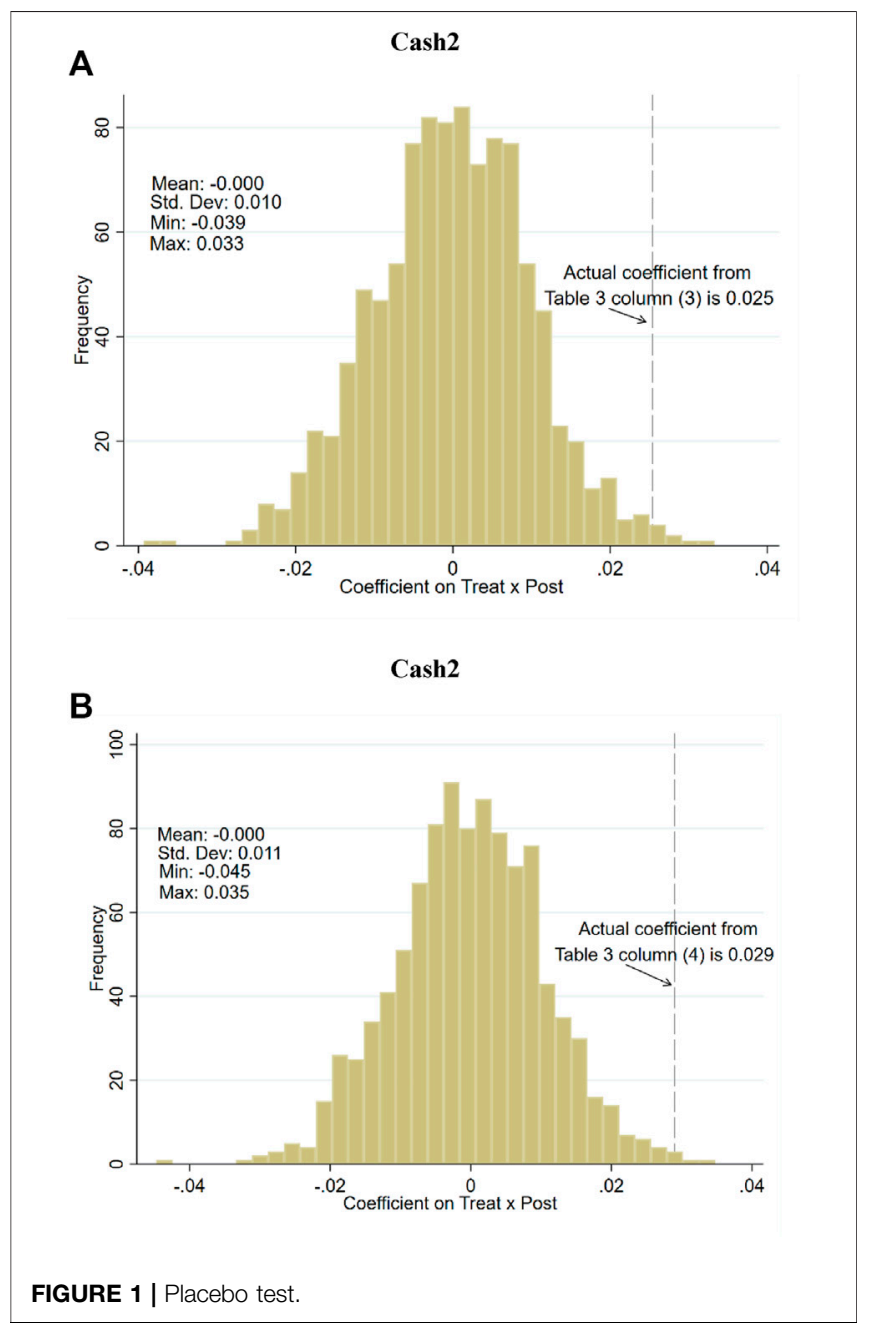

distribution of the coefficients on Treat $\times$ Post based on those pseudo-treatment-group when the dependent variable is Cash1. The actual coefficient on Treat $\times$ Post of 0.025 from column 3 ) of Table 3 lies well to the right of the entire distribution of coefficient estimates from the placebo test. Panel B of Figure 1 plots the empirical distribution of the coefficients on Treat $\times$ Post based on those pseudo-treatment-group when the dependent variable is Cash2. The actual coefficient on Treat $\times$ Post of 0.029 from column 4) of Table 3 lies well to the right of the entire distribution of coefficient estimates from the placebo test. In the second placebo test, following Cai et al. (2021) and Chen et al. (2021), we re-estimate our baseline regression based on a pseudo-treatment year: 2010 (4 years before the actual year in which the new EPL was promulgated). We obtain the 7 year data around the pseudo-treatment year including 3 years before and 3 years after. We present the results in columns 5) and 6) of Table 6. The coefficients on Treat $\times$ Post are -0.000 and 0.000 , both of which are close to zero and not significant. Overall, the results of the placebo tests could help alleviate the concern that our results are driven by chance or the overall time trend.

\section{ECONOMIC CHANNELS}

Based on our previous theoretical analysis, environmental regulation may affect corporate cash holdings by reducing the access to bank loans, decreasing the access to subsidies, and improving environmental uncertainty. In this section, we try to examine the potential channels through which environmental regulation affects corporate cash holdings.

To examine the economic channel, we use the mediation model pioneered by Baron and Kenny (1986), which has been used extensively in subsequent research (e.g., Avom et al., 2020; Zhu et al., 2020; Huang et al., 2021). Therefore, we construct models 2) and 3) to examine the plausible channels:

$$
\begin{gathered}
\text { Mediated }_{i, t}=\alpha+\mathrm{a}\left(\text { Treat }_{i, t} \times \text { Post }_{i, t}\right)+9 X_{i, t}+\gamma_{i}+\delta_{t}+\varepsilon_{i, t} \\
\text { Cash }_{i, t}=\alpha+\mathrm{c}\left(\text { Treat }_{i, t} \times \text { Post }_{i, t}\right)+\mathrm{b} \text { Mediated }_{i, t}+9 X_{i, t}+\gamma_{i}+\delta_{t} \\
+\varepsilon_{i, t}
\end{gathered}
$$

where Mediated is the mediating variable. The first step of mediation model is to examine the significance of coefficient $\beta$ in model 1), which is statistically significant based on the results from Table 3. If the coefficients of $a$ and $b$ in models 2) and 3), 
TABLE 7 | Mechanism analysis: Environmental uncertainty.

\begin{tabular}{|c|c|c|c|}
\hline \multirow[t]{2}{*}{ Dependent variable $=$} & \multirow{2}{*}{$\frac{c V}{\text { (1) }}$} & \multirow{2}{*}{$\frac{\text { Cash1 }}{\text { (2) }}$} & \multirow{2}{*}{$\frac{\text { Cash2 }}{(3)}$} \\
\hline & & & \\
\hline Treat $\times$ Post & $\begin{array}{l}0.100^{*} \\
(0.058)\end{array}$ & $\begin{array}{c}0.020^{\star \star \star} \\
(0.006)\end{array}$ & $\begin{array}{c}0.024^{\star \star \star} \\
(0.007)\end{array}$ \\
\hline $\mathrm{CV}$ & & $\begin{array}{c}0.003^{\star \star \star} \\
(0.001)\end{array}$ & $\begin{array}{c}0.003^{\star \star \star} \\
(0.001)\end{array}$ \\
\hline Control variables & YES & YES & YES \\
\hline Firm fixed effects & YES & YES & YES \\
\hline Year fixed effects & YES & YES & YES \\
\hline $\mathrm{N}$ & 17,774 & 17,774 & 17,774 \\
\hline$R^{2}$ & 0.398 & 0.647 & 0.638 \\
\hline
\end{tabular}

TABLE 8 | Mechanism analysis: Bank loans.

\begin{tabular}{|c|c|c|c|}
\hline \multirow[t]{2}{*}{ Dependent variable $=$} & \multirow{2}{*}{$\begin{array}{c}\text { Loans } \\
\text { (1) }\end{array}$} & \multirow{2}{*}{$\begin{array}{c}\text { Cash1 } \\
\text { (2) }\end{array}$} & \multirow{2}{*}{$\frac{\text { Cash2 }}{\text { (3) }}$} \\
\hline & & & \\
\hline Treat $\times$ Post & $\begin{array}{c}-0.018^{\star * \star} \\
(0.005)\end{array}$ & $\begin{array}{l}0.022^{\star *} \\
(0.009)\end{array}$ & $\begin{array}{l}0.025^{\star \star} \\
(0.010)\end{array}$ \\
\hline Loans & & $\begin{array}{c}-0.263^{\star \star \star} \\
(0.020)\end{array}$ & $\begin{array}{c}-0.251^{\star \star \star} \\
(0.022)\end{array}$ \\
\hline Control variables & YES & YES & YES \\
\hline Firm fixed effects & YES & YES & YES \\
\hline Year fixed effects & YES & YES & YES \\
\hline$N$ & 19,573 & 19,573 & 19,573 \\
\hline$R^{2}$ & 0.775 & 0.654 & 0.643 \\
\hline
\end{tabular}

Control variables are firm size (Size), capital expenditure (CapEx), firm growth (Growth), Return on equity (ROE), operating cash flow (CF), Tobin's $Q$ (TBQ), the dividend dummy (Dividend), and state ownership (SOE), respectively. Standard errors clustered at the industry level are reported in parentheses. *, **, and ${ }^{* * *}$ denote significance at the level of 10,5 , and $1 \%$, respectively.

respectively, are all statistically significant, Mediated is the potential channel through which environmental regulation affects corporate cash holdings. Besides, under the above condition, if the coefficient of $c$ is statistically significant, the mediating variables partially mediate the relations between the environmental regulation and corporate cash holdings. Otherwise, the mediating variable plays a completely mediating role.

\subsection{The Channel of Environmental Uncertainty}

Following prior studies (Ghosh and Olsen, 2009; Huang et al., 2017), we use the $\mathrm{CV}$ index as the proxy for environmental uncertainty $(C V)$. We first calculate the raw sales volatility over a rolling 3 year period and then normalize the raw firm-specific environmental uncertainty by dividing it by the average environmental uncertainty for that firm's industry for the same fiscal year to mitigate time and industry effects. The regression results are shown in column 1) of Table 7, the coefficient on Treat $\times$ Post is positive and significant, suggesting that there is a significant increase in environmental uncertainty for heavy-polluting firms after the EPL promulgation. Our results in Columns 2) and 3) of Table 7
TABLE 9 | Mechanism analysis: Subsidies.

\begin{tabular}{|c|c|c|c|}
\hline \multirow[t]{2}{*}{ Dependent variable $=$} & Subsidies & Cash1 & Cash2 \\
\hline & (1) & (2) & (3) \\
\hline \multirow[t]{2}{*}{ Treat $\times$ Post } & $-0.119^{\star \star}$ & $0.027^{\star \star \star}$ & $0.030^{\star \star \star}$ \\
\hline & $(0.054)$ & $(0.010)$ & $(0.011)$ \\
\hline \multirow[t]{2}{*}{ Subsidies } & & $-0.001^{*}$ & $-0.002^{\star \star \star}$ \\
\hline & & $(0.001)$ & $(0.001)$ \\
\hline Control variables & YES & YES & YES \\
\hline Firm fixed effects & YES & YES & YES \\
\hline Year fixed effects & YES & YES & YES \\
\hline $\mathrm{N}$ & 18,458 & 18,458 & 18,458 \\
\hline$R^{2}$ & 0.639 & 0.652 & 0.640 \\
\hline
\end{tabular}

Standard errors clustered at the industry level are reported in parentheses. *, **, and *** denote significance at the level of 10,5 , and $1 \%$, respectively.

show that the heavy-polluting firms hold more cash after the implementation of the new EPL and that the new EPL indeed increases heavy-polluting firms' environmental uncertainty. These findings are consistent with our conjecture that environmental uncertainty partially mediates the positive relationship between the new EPL and corporate cash holdings, and support H2. That is, the new EPL improves heavy-polluting firms' cash holdings by increasing their environmental uncertainty.

\subsection{The Channel of Access to Bank Loans}

We use the ratio of firms' total amount of bank loans to total assets (e.g., Chang et al., 2021) as the proxy for the bank loans (Loans). Regression results for the mediation model are reported in Table 8. As shown in column 1) of Table 8, the coefficient of the interaction terms of Treat $\times$ Post is negative and significant at the $1 \%$ level, which means that heavy-polluting firms experience a significant decline in bank loans after the implementation of the new EPL compared to control firms. After controlling Loans, we find that heavy-polluting firms significantly increase the level of their cash holdings and that the coefficients of Loans in columns 2) and 3) are also significant and negative, consistent with our predictions. This suggests that access to bank loans partially mediates the positive relationship between environmental regulation and corporate cash holdings, and supports $H 3$. That is, environmental regulation induces heavy-polluting firms to increase their cash holdings by limiting their access to bank loans.

\subsection{The Channel of Access to Government Subsidies}

Following Chang et al. (2021) and Qiao and Fei (2022), we use the natural logarithm of government subsidies as the proxy for government subsidies (Subsidies). The results in column 1) of Table 9 show that there is a significant decline in government subsidies for heavy-polluting firms after the introduction of the new EPL. In columns 2) and 3) of Table 9, after controlling Subsidies, we still find that environmental regulation can positively affect heavy-polluting firms' cash holdings and that the coefficients of Subsidies are also significant and negative. These results are consistent with our expectations, indicating that access to government subsidies partially mediates the positive 
TABLE 10 | The effect of firms' investment and growth opportunities.

\begin{tabular}{|c|c|c|c|c|}
\hline \multirow[t]{2}{*}{ Dependent variable $=$} & Cash1 & Cash2 & Cash1 & Cash2 \\
\hline & (1) & (2) & (3) & (4) \\
\hline Treat $\times$ Post & $\begin{array}{c}0.033^{\star \star \star} \\
(0.009)\end{array}$ & $\begin{array}{c}0.038^{\star \star \star} \\
(0.010)\end{array}$ & & \\
\hline$T B Q$ & $\begin{array}{c}0.017^{\star \star \star} \\
(0.005)\end{array}$ & $\begin{array}{l}0.013^{\star \star} \\
(0.005)\end{array}$ & & \\
\hline Treat $\times$ Post $\times T B Q$ & $\begin{array}{c}-0.020^{\star \star \star} \\
(0.004)\end{array}$ & $\begin{array}{c}-0.022^{\star \star \star} \\
(0.004)\end{array}$ & & \\
\hline Treat $\times$ Post & & & $\begin{array}{c}0.025^{\star \star \star} \\
(0.009)\end{array}$ & $\begin{array}{c}0.028^{\star \star \star} \\
(0.010)\end{array}$ \\
\hline CapexGrowth & & & $\begin{array}{c}0.009^{\star \star \star} \\
(0.001)\end{array}$ & $\begin{array}{c}0.010^{\star \star \star} \\
(0.001)\end{array}$ \\
\hline Treat $\times$ Post $\times$ CapexGrowth & & & $\begin{array}{c}-0.006^{\star \star \star} \\
(0.002)\end{array}$ & $\begin{array}{c}-0.006^{\star \star \star} \\
(0.002)\end{array}$ \\
\hline Control variables & YES & YES & YES & YES \\
\hline Firm fixed effects & YES & YES & YES & YES \\
\hline Year fixed effects & YES & YES & YES & YES \\
\hline N & 19,573 & 19,573 & 18,688 & 18,688 \\
\hline$R^{2}$ & 0.644 & 0.634 & 0.650 & 0.643 \\
\hline
\end{tabular}

Standard errors clustered at the industry level are reported in parentheses. *, **, and *** denote significance at the level of 10, 5, and 1\%, respectively.

relationship between environmental regulation and corporate cash holdings, and support H4. That is, environmental regulation increases heavy-polluting firms' cash holdings by hampering their access to government subsidies.

\section{ADDITIONAL TESTS}

\subsection{Precautionary Motive}

To examine whether environmental regulation can positively affect corporate cash holdings through the precautionary effects, we conduct further empirical analyses. According to the precautionary motive, heavy-polluting firms with strong growth potential are less likely to increase their cash reserves as a result of the stringent environmental regulation, and they are inclined to invest capital resources to pursue future growth (Cai et al., 2021). There should be significant differences following a change in environmental regulation between firms with high and low investment growth opportunities in terms of their liquidity management. Following Cai et al. (2021), we measure firms' investment and growth prospects using Tobin's $\mathrm{Q}(T B Q)$ and the annual growth of capital expenditure (CapexGrowth) and interact with those with Treat $\times$ Post to examine whether heavypolluting firms with high growth prospects are more sensitive to the new EPL shocks. If the precautionary effect holds, we expect the estimated coefficients of the triple interaction term (i.e., Treat $\times$ Post $\times T B Q$ and Treat $\times$ Post $\times$ CapexGrowth) to be significantly negative.

The regression results are presented in Table 10. In columns 1) and 2), the coefficients of the triple interaction term Treat $\times$ Post $\times$ TBQ are negative and statistically significant at the $1 \%$ level irrespective of the measures of cash holdings. As reported in columns 3) and 4), the triple interaction term Treat $\times$ Post $\times$ CapexGrowth is negative and statistically significant at the $1 \%$ level. These results suggest that the impact of the environmental regulation on corporate cash holdings is more pronounced among heavy-polluting firms with strong growth prospects, which strongly supports the precautionary motive.

\subsection{Political Relations-Based}

Political connections may weaken the effectiveness of regulation and enforcement for the new EPL (Liu X. et al., 2021). Heavy-polluting firms with strong political connections may be less affected by the new EPL and should experience an insignificantly small change in their cash holdings. However, heavy-polluting firms without political backgrounds can have disadvantages in facing more effective regulation enforcement after the promulgation of the new EPL, leading to a significant increase in cash holdings. We divide our sample into subsamples based on firms' political connections and estimate the regression model in the model 1) using each of the subsamples. Table 11 presents the estimation results. The coefficients of Treat $\times$ Post are close to 0 and statistically insignificant in columns 1) and 3), while they are positive and significant for the other subsamples. These results show that the increase in cash holdings in the post-regulation period to be more evident among heaving-polluting firms with non-politically connections. This finding indicates that heavy-polluting firms with political backgrounds can gain political assistance, and thus they experience an insignificant decline in bank loans and government subsidies, and an insignificant increase in environmental uncertainty, which brings about a smaller change in their cash holdings following the promulgation of the new EPL.

\subsection{Economic Dependence on Secondary Sector}

Compared to the primary sector and tertiary sector, the secondary sector including coal, metallurgy, mining, thermal power, iron, and steel, contributes most to both economic growth and environmental pollution (Hao and Liu, 2016; Zhu et al., 2019; Liu Y. et al., 2021). However, there is a strong linkage between the private interests of provincial leaders and regional economic development ( $\mathrm{Li}$ and Zhou, 2005; Li X. et al., 2019). That is, regional economic growth matters in determining the promotion of political officials. The "race to the bottom" theory argues that strategic interaction among political jurisdictions inhibits the stringency of environmental regulation (Woods, 2006). Thus, if one province relies more on the secondary sector, government officials tend to reduce the enforcement of environmental regulation to lower the expense of economic growth (Liu Y. et al., 2021). A quantitative proxy for secondary sector intensity is defined as the value-added of the secondary sector divided by the value-added of three sectors. A higher value means that a province has a higher secondary sector intensity. We assign sample provinces to high and low groups of secondary sector intensity based on the median value of each year. In Table 12, the regression results show that the effect of the new EPL appears to be stronger in the sample of the low secondarysector-intensity group. These results indicate that 
TABLE 11 | Heterogeneous Effects of environmental regulation on corporate cash holdings.

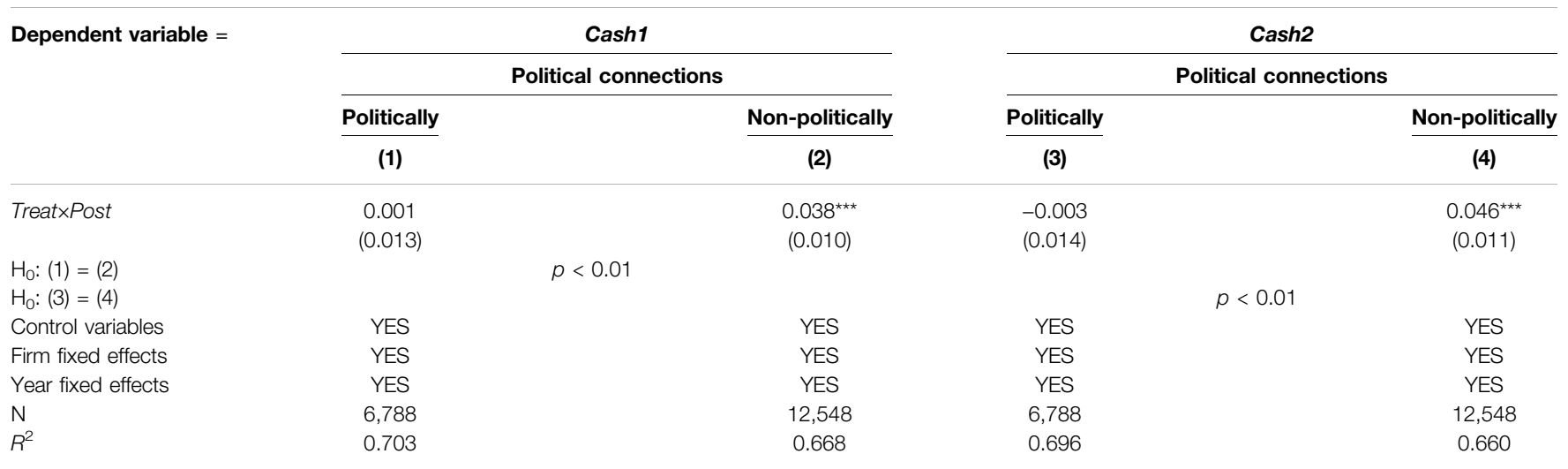

Standard errors clustered at the industry level are reported in parentheses. *, **, and ${ }^{* * *}$ denote significance at the level of 10, 5, and 1\%, respectively.

TABLE 12 | Heterogeneous Effects of environmental regulation on corporate cash holdings.

Dependent variable $=$

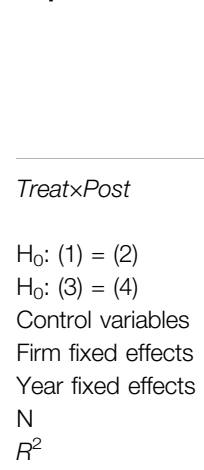

Cash1

\begin{tabular}{|c|c|}
\hline \multicolumn{2}{|c|}{ Dependence on secondary industry } \\
\hline High & Low \\
\hline (1) & (2) \\
\hline $0.017^{*}$ & $0.025^{\star *}$ \\
\hline$(0.009)$ & $(0.011)$ \\
\hline \multicolumn{2}{|c|}{$p<0.01$} \\
\hline YES & YES \\
\hline YES & YES \\
\hline YES & YES \\
\hline 7,609 & 11,722 \\
\hline 0.667 & 0.672 \\
\hline
\end{tabular}

Cash2

\begin{tabular}{ccc}
\hline \multicolumn{3}{c}{ Dependence on secondary industry } \\
\cline { 1 - 1 } High & & Low \\
$(3)$ & $(4)$ \\
$0.020^{\star}$ & $0.029^{\star *}$ \\
$(0.010)$ & $(0.013)$
\end{tabular}

$p<0.01$

YES

YES

YES

7,609

0.652
(4)

(0.013)

YES

YES

YES

11,722

0.668

Standard errors clustered at the industry level are reported in parentheses. *, **, and ${ }^{* * *}$ denote significance at the level of 10,5 , and $1 \%$, respectively.

environmental regulation is less effective in the regions with more dependent on the secondary sector, which leads to the weaker effect of the new EPL on corporate cash holdings.

\section{DISCUSSION AND CONCLUSION}

\subsection{Discussion}

This paper analyzes the impact of environmental regulation on heavy-polluting firms' cash decision-making. Due to data limitations, we only focus on the listed firms in China. Future research can analyze the effects of environmental regulation on different types of firms, such as private companies and foreign firms. On the other hand, we suggest more research studies on the economic consequences of environmental regulation on corporate-level activities in the future, thus providing sufficient scientific support for the formulation of environmental regulation policies and protection of the environment.

\subsection{Conclusion}

In this study, we investigate how environmental regulation triggered by the new EPL in China affects public firms' cash decision-making. Exploiting the new EPL as an exogenous shock to environmental regulation, we conduct a quasiexperiment to identify the causal effect of stricter environmental regulation on corporate cash holdings. Our results show that heavy-polluting firms increase their cash holding significantly after the introduction of the new EPL, which provides support for the precautionary effect. We show that the new EPL positively affects firms' cash holdings mainly through heightened environmental uncertainty and limited access to banks loans and government subsidies. In addition, we show that the stringency of environmental regulation increases the level of heavy-polluting firms' cash holdings, and the effects are more pronounced for firms without stronger political connections and those in regions with less dependent on the secondary sector. 
Our results here have important theoretical and practical implications. First, heavy-polluting firms pursue liquid strategies by maintaining suitable cash reserves because the new EPL leads to heightened uncertainty for them. Because holding cash is costly for firms, this result suggests that a hidden cost of regulation is that it increases the environmental uncertainty faced by firms. Second, the new EPL aiming to strengthen the stringent environmental regulation may have unintended side effects that worsen firms' financial constraints when there are frictions to finance, especially in developing countries in which businesses rely heavily on bank loans. As a result, while developing environmental rules, governments should take into consideration corporate liquidity. Third, stricter environmental regulation is associated with the re-allocation of government subsidies. To achieve sustainable development and environmental protection, the governments in China prefer to encourage the development of non-heavy-polluting industries, such as new energy industries, instead of heavy-polluting industries. Finally, governments should encourage the banks to provide more loans to heavy-polluting firms according to their environmental performance, so that they have more funds

\section{REFERENCES}

Abadie, A., Drukker, D., Herr, J. L., and Imbens, G. W. (2004). Implementing Matching Estimators for Average Treatment Effects in Stata. Stata J. 4 (3), 290-311. doi:10.1177/1536867x0400400307

Adebayo, T. S., and Kirikkaleli, D. (2021). Impact of Renewable Energy Consumption, Globalization, and Technological Innovation on Environmental Degradation in Japan: Application of Wavelet Tools. Environ. Dev. Sustainability 23, 16057-16082. doi:10.1007/s10668-02101322-2

Adebayo, T. S., and Rjoub, H. (2021). A New Perspective into the Impact of Renewable and Nonrenewable Energy Consumption on Environmental Degradation in Argentina: A Time-Frequency Analysis. Environ. Sci. Pollut. Res., 1-17. doi:10.1007/s11356-021-16897-6

Adebayo, T. S., Oladipupo, S. D., Adeshola, I., and Rjoub, H. (2021a). Wavelet Analysis of Impact of Renewable Energy Consumption and Technological Innovation on $\mathrm{CO} 2$ Emissions: Evidence from Portugal. Environ. Sci. Pollut. Res., 1-18. doi:10.1007/s11356-021-17708-8

Adebayo, T. S., Rjoub, H., Akadiri, S. S., Oladipupo, S. D., Sharif, A., and Adeshola, I. (2021b). The Role of Economic Complexity in the Environmental Kuznets Curve of MINT Economies: Evidence from Method of Moments Quantile Regression. Environ. Sci. Pollut. Res., 1-13. doi:10.1007/s11356-021-17524-0

Aintablian, S., Mcgraw, P. A., and Roberts, G. S. (2007). Bank Monitoring and Environmental Risk. J. Business Finance Account. 34 (1-2), 389-401. doi:10.1111/j.1468-5957.2006.00644.x

Anser, M. K., Usman, M., Godil, D. I., Shabbir, M. S., Sharif, A., Tabash, M. I., et al. (2021a). Does Globalization Affect the Green Economy and Environment? the Relationship between Energy Consumption, Carbon Dioxide Emissions, and Economic Growth. Environ. Sci. Pollut. Res. 28 (37), 51105-51118. doi:10.1007/ s11356-021-14243-4

Anser, M. K., Usman, M., Sharif, M., Bashir, S., Shabbir, M. S., Yahya Khan, G., et al. (2021b). The Dynamic Impact of Renewable Energy Sources on Environmental Economic Growth: Evidence from Selected Asian Economies. Environ. Sci. Pollut. Res., 1-13. doi:10.1007/s11356-021-17136-8

Arslan, Z., Kausar, S., Kannaiah, D., Shabbir, M. S., Khan, G. Y., and Zamir, A. (2021). The Mediating Role of Green Creativity and the Moderating Role of Green Mindfulness in the Relationship Among Clean Environment, Clean Production, and Sustainable Growth. Environ. Sci. Pollut. Res., 1-15. doi:10.1007/s11356-021-16383-z to meet the necessary needs of green investment, R\&D investment, and innovative products.

\section{DATA AVAILABILITY STATEMENT}

The raw data supporting the conclusion of this article will be made available by the authors, without undue reservation.

\section{AUTHOR CONTRIBUTIONS}

CZ designed the main idea, collected the data, and run the regressions. JC wrote the manuscript and modified the research design. All authors revised this paper many times.

\section{FUNDING}

This research was funded by the Fundamental Research Funds for the Central Universities, and the Research Funds of Renmin University of China (Grant No. 20XNH057).

Avom, D., Nkengfack, H., Fotio, H. K., and Totouom, A. (2020). ICT and Environmental Quality in Sub-Saharan Africa: Effects and Transmission Channels. Technol. Forecast. Soc. Change 155, 120028. doi:10.1016/ j.techfore.2020.120028

Baron, R. M., and Kenny, D. A. (1986). The Moderator-Mediator Variable Distinction in Social Psychological Research: Conceptual, Strategic, and Statistical Considerations. J. Personal. Soc. Psychol. 51 (6), 1173-1182. doi:10.1037/0022-3514.51.6.1173

Bartlett, R., and Partnoy, F. (2020). The Misuse of Tobin's Q. Vand. L. Rev. 73, 353. doi: $10.2139 /$ ssrn.3118020

Brealey, R. A., Myers, S. C., Allen, F., and Mohanty, P. (2018). Principles of Corporate Finance, 12. New York: McGraw-Hill Education.

Cai, W., and Ye, P. (2020). How Does Environmental Regulation Influence Enterprises' Total Factor Productivity? A Quasi-Natural experiment Based on China's New Environmental protection Law. J. Clean. Prod. 276, 124105. doi:10.1016/j.jclepro.2020.124105

Cai, W., Hu, F., Xu, F., and Zheng, L. (2021). Anti-Corruption Campaign and Corporate Cash Holdings: Evidence from China. Emerging Markets Rev., 100843. doi:10.1016/j.ememar.2021.100843

Campello, M., Graham, J. R., and Harvey, C. R. (2010). The Real Effects of Financial Constraints: Evidence from a Financial Crisis. J. Financial Econ. 97 (3), 470-487. doi:10.1016/j.jfineco.2010.02.009

Caragnano, A., Mariani, M., Pizzutilo, F., and Zito, M. (2020). Is it Worth Reducing GHG Emissions? Exploring the Effect on the Cost of Debt Financing. J. Environ. Manage. 270, 110860. doi:10.1016/j.jenvman.2020.110860

Chang, Y., Pan, X., Wang, J., and Zhou, Q. (2021). Depoliticization and Corporate Cash Holdings: Evidence from the Mandated Resignation of Directors in China. J. Corporate Finance 69, 102004. doi:10.1016/j.jcorpfin.2021.102004

Chen, T., Gao, H., and Wang, Y. (2021). Tariff Uncertainty and Firm Innovation: Evidence from the U.S.-China Permanent Normal Trade Relation. J. Empirical Finance 62, 12-27. doi:10.1016/j.jempfin.2021.02.002

Cull, R., and Xu, L. C. (2000). Bureaucrats, State Banks, and the Efficiency of Credit Allocation: The Experience of Chinese State-Owned Enterprises. J. Comp. Econ. 28 (1), 1-31. doi:10.1006/jcec.1999.1642

Davydova, Y., and Sokolov, V. (2014). The Real Effects of Financial Constraints: Evidence from a Debt Subsidization Program Targeted at Strategic Firms. J. Empirical Finance 29, 247-265. doi:10.1016/j.jempfin.2014.07.006

Deng, K., Ding, Z., Liao, X., and Zhu, Y. (2021). Staged Subsidies and Corporate Investments: Evidence from Chinese Listed Firms. Pacific-Basin Finance J. 68, 101620. doi:10.1016/j.pacfin.2021.101620 
Ding, X., Appolloni, A., and Shahzad, M. (2021). Environmental Administrative Penalty, Corporate Environmental Disclosures and the Cost of Debt. J. Clean. Prod. 332, 129919. doi:10.1016/j.jclepro.2021.129919

Falk, R. L., and Wee, J. (2015). China's New Environmental Protection Law. Envtl. L. Rep. News Anal. 45, 10023. Available at heinonline.org/HOL/LandingPage? handle=hein.journals/elrna45\&div $=8$

Fang, J., Liu, C., and Gao, C. (2019). The Impact of Environmental Regulation on Firm Exports: Evidence from Environmental Information Disclosure Policy in China. Environ. Sci. Pollut. Res. 26 (36), 37101-37113. doi:10.1007/s11356-01906807-2

Ferreira, M. A., and Vilela, A. S. (2004). Why Do Firms Hold Cash? Evidence from EMU Countries. Eur. Financial Manage. 10 (2), 295-319. doi:10.1111/j.13547798.2004.00251.x

Firth, M., Malatesta, P. H., Xin, Q., and Xu, L. (2012). Corporate Investment, Government Control, and Financing Channels: Evidence from China's Listed Companies. J. Corporate Finance 18 (3), 433-450. doi:10.1016/ j.jcorpfin.2012.01.004

Galloway, E., and Johnson, E. P. (2016). Teaching an Old Dog New Tricks: Firm Learning from Environmental Regulation. Energ. Econ. 59, 1-10. doi:10.1016/ j.eneco.2016.06.023

García-Quevedo, J., and Jové-Llopis, E. (2021). Environmental Policies and Energy Efficiency Investments. An Industry-Level Analysis. Energy Policy 156, 112461. doi:10.1016/j.enpol.2021.112461

Ghosh, D., and Olsen, L. (2009). Environmental Uncertainty and Managers' Use of Discretionary Accruals. Account. Organizations Soc. 34 (2), 188-205. doi:10.1016/j.aos.2008.07.001

Gilchrist, S., Sim, J. W., and Zakrajšek, E. (2014). Uncertainty, Financial Frictions, and Investment Dynamics. Cambridge, Massachusetts: National Bureau of Economic Research.

Girma, S., Görg, H., and Strobl, E. (2007). The Effect of Government Grants on Plant Level Productivity. Econ. Lett. 94 (3), 439-444. doi:10.1016/ j.econlet.2006.09.003

Han, S., and Qiu, J. (2007). Corporate Precautionary Cash Holdings. J. Corporate Finance 13 (1), 43-57. doi:10.1016/j.jcorpfin.2006.05.002

Hao, Y., and Liu, Y.-M. (2016). The Influential Factors of Urban PM2.5 Concentrations in China: a Spatial Econometric Analysis. J. Clean. Prod. 112, 1443-1453. doi:10.1016/j.jclepro.2015.05.005

Harford, J., Mansi, S. A., and Maxwell, W. F. (2008). Corporate Governance and Firm Cash Holdings in the US. J. Financial Econ. 87 (3), 535-555. doi:10.1016/ j.jineco.2007.04.002

Hasan, M. M., Habib, A., and Zhao, R. (2021). Corporate Reputation Risk and Cash Holdings. Account. Finance, 41. doi:10.1111/acfi.12803

Huang, H., Sun, L., and Zhang, J. (2017). Environmental Uncertainty and Tax Avoidance. Adv. taxation 24, 83-124. doi:10.1108/s1058749720170000024002:

Huang, J., Chen, Y., Dai, X., and Ni, X. (2021). Stock Market Liberalisation and Corporate Cash Holdings: Evidence from China. Account. Finance, 31. doi:10.1111/acfi.12844

Jaffe, A. B., and Palmer, K. (1997). Environmental Regulation and Innovation: A Panel Data Study. Rev. Econ. Stat. 79 (4), 610-619. doi:10.1162/ 003465397557196

Jebran, K., Iqbal, A., Bhat, K. U., Khan, M. A., and Hayat, M. (2019). Determinants of Corporate Cash Holdings in Tranquil and Turbulent Period: Evidence from an Emerging Economy. Financial Innov. 5 (1), 1-12. doi:10.1186/s40854-0180116-y

Jin, W., Zhang, H.-q., Liu, S.-s., and Zhang, H.-b. (2019). Technological Innovation, Environmental Regulation, and Green Total Factor Efficiency of Industrial Water Resources. J. Clean. Prod. 211, 61-69. doi:10.1016/ j.jclepro.2018.11.172

Jun, W., Mughal, N., Zhao, J., Shabbir, M. S., Niedbała, G., Jain, V., et al. (2021). Does Globalization Matter for Environmental Degradation? Nexus Among Energy Consumption, Economic Growth, and Carbon Dioxide Emission. Energy Policy 153 (3), 112230. doi:10.1016/j.enpol.2021.112230

Kesidou, E., and Demirel, P. (2012). On the Drivers of Eco-Innovations: Empirical Evidence from the UK. Res. Pol. 41 (5), 862-870. doi:10.1016/ j.respol.2012.01.005

Khan, I., Hou, F., and Le, H. P. (2021a). The Impact of Natural Resources, Energy Consumption, and Population Growth on Environmental Quality: Fresh
Evidence from the United States of America. Sci. Total Environ. 754, 142222. doi:10.1016/j.scitotenv.2020.142222

Khan, M. B., Saleem, H., Shabbir, M. S., and Huobao, X. (2021b). The Effects of Globalization, Energy Consumption and Economic Growth on Carbon Dioxide Emissions in South Asian Countries. Energ. Environ., 958305X-20986896X. doi:10.1177/0958305x20986896

Kim, J., Kim, H., and Woods, D. (2011). Determinants of Corporate Cash-Holding Levels: An Empirical Examination of the Restaurant Industry. Int. J. Hospitality Manage. 30 (3), 568-574. doi:10.1016/j.ijhm.2010.10.004

Kirikkaleli, D., and Adebayo, T. S. (2021). Do Renewable Energy Consumption and Financial Development Matter for Environmental Sustainability? New Global Evidence. Sustain. Dev. 29 (4), 583-594. doi:10.1002/sd.2159

Lanoie, P., Patry, M., and Lajeunesse, R. (2008). Environmental Regulation and Productivity: Testing the Porter Hypothesis. J. Prod. Anal. 30 (2), 121-128. doi:10.1007/s11123-008-0108-4

Lee, C.-C., and Wang, C.-W. (2021). Firms' Cash Reserve, Financial Constraint, and Geopolitical Risk. Pacific-Basin Finance J. 65, 101480. doi:10.1016/ j.pacfin.2020.101480

Lee, C. J. (2001). Financial Restructuring of State Owned Enterprises in China: The Case of Shanghai Sunve Pharmaceutical Corporation. Account. Organizations Soc. 26 (7-8), 673-689. doi:10.1016/s0361-3682(00)00007-6

Leiter, A. M., Parolini, A., and Winner, H. (2009). Environmental regulation and investment: Evidence from European industry data. Ecological Economics 70 (4), 759-770. doi:10.1016/j.ecolecon.2010.11.013

Li, H., and Zhou, L. (2005). Political Turnover and Economic Performance: The Incentive Role of Personnel Control in China. J. Public Econ. 89 (9-10), 1743-1762. doi:10.1016/j.jpubeco.2004.06.009

Li, K., Fang, L., and He, L. (2019). How Population and Energy Price Affect China's Environmental Pollution? Energy Policy 129, 386-396. doi:10.1016/ j.enpol.2019.02.020

Li, X., Liu, C., Weng, X., and Zhou, L.-A. (2019). Target Setting in Tournaments: Theory and Evidence from China. Econ. J. 129 (623), 2888-2915. doi:10.1093/ ej/uez018

Li, Y., Zeng, B., Wu, T., and Hao, H. (2019). Effects of Urban Environmental Policies on Improving Firm Efficiency: Evidence from Chinese New Energy Vehicle Firms. J. Clean. Prod. 215, 600-610. doi:10.1016/ j.jclepro.2019.01.099

Liao, X., and Shi, X. (2018). Public Appeal, Environmental Regulation and Green Investment: Evidence from China. Energy Policy 119, 554-562. doi:10.1016/ j.enpol.2018.05.020

Lin, C., Schmid, T., and Weisbach, M. S. (2021). Product Price Risk and Liquidity Management: Evidence from the Electricity Industry. Manage. Sci. 67 (4), 2519-2540. doi:10.1287/mnsc.2020.3579

Liu, Q., Pan, X., and Tian, G. G. (2018). To what Extent Did the Economic Stimulus Package Influence Bank Lending and Corporate Investment Decisions? Evidence from China. J. Banking Finance 86, 177-193. doi:10.1016/ j.jbankfin.2016.04.022

Liu, X., Xu, H., and Lu, M. (2021). Do auditors Respond to Stringent Environmental Regulation? Evidence from China's New Environmental protection Law. Econ. Model. 96, 54-67. doi:10.1016/ j.econmod.2020.12.029

Liu, Y., Wang, A., and Wu, Y. (2021). Environmental Regulation and Green Innovation: Evidence from China's New Environmental Protection Law. J. Clean. Prod. 297, 126698. doi:10.1016/j.jclepro.2021.126698

Lopez, J. M. R., Sakhel, A., and Busch, T. (2017). Corporate Investments and Environmental Regulation: The Role of Regulatory Uncertainty, RegulationInduced Uncertainty, and Investment History. Eur. Manage. J. 35 (1), 91-101. doi:10.1016/j.emj.2016.06.004

Madsen, P. M. (2009). Does Corporate Investment Drive a "Race to the Bottom" in Environmental Protection? A Reexamination of the Effect of Environmental Regulation on Investment. Amj 52 (6), 1297-1318. doi:10.5465/ amj.2009.47085173

Magerakis, E., and Habib, A. (2021). Environmental Uncertainty and Corporate Cash Holdings: The Moderating Role of CEO Ability. Int. Rev. Finance, 31. doi:10.1111/irfi.12355

Mughal, N., Arif, A., Jain, V., Chupradit, S., Shabbir, M. S., Ramos-Meza, C. S., et al. (2022). The Role of Technological Innovation in Environmental 
Pollution, Energy Consumption and Sustainable Economic Growth: Evidence from South Asian Economies. Energ. Strategy Rev. 39, 100745. doi:10.1016/ j.esr.2021.100745

Muhammad, I., Shabbir, M. S., Saleem, S., Bilal, K., and Ulucak, R. (2021). Nexus between Willingness to Pay for Renewable Energy Sources: Evidence from Turkey. Environ. Sci. Pollut. Res. 28 (3), 2972-2986. doi:10.1007/s11356-02010414-x

Nyborg, K. G., and Wang, Z. (2021). The Effect of Stock Liquidity on Cash Holdings: The Repurchase Motive. J. Financial Econ. 142 (2), 905-927. doi:10.1016/j.jfineco.2021.05.027

O'Connor, N. G., Deng, J., and Luo, Y. (2006). Annex I.1. OECD State-Owned Enterprises. Account. Organ. Soc. 31 (2), 157-178. doi:10.1787/97892640094319-en

Opler, T., Pinkowitz, L., Stulz, R., and Williamson, R. (1999). The Determinants and Implications of Corporate Cash Holdings. J. Financial Econ. 52 (1), 3-46. doi:10.1016/s0304-405x(99)00003-3

Ouyang, X., Li, Q., and Du, K. (2020). How Does Environmental Regulation Promote Technological Innovations in the Industrial Sector? Evidence from Chinese Provincial Panel Data. Energy Policy 139, 111310. doi:10.1016/ j.enpol.2020.111310

Ozkan, A., and Ozkan, N. (2004). Corporate Cash Holdings: An Empirical Investigation of UK Companies. J. Banking Finance 28 (9), 2103-2134. doi:10.1016/j.jbankfin.2003.08.003

Phan, H. V., Nguyen, N. H., Nguyen, H. T., and Hegde, S. (2019). Policy Uncertainty and Firm Cash Holdings. J. Business Res. 95, 71-82. doi:10.1016/j.jbusres.2018.10.001

Pizzutilo, F., Mariani, M., Caragnano, A., and Zito, M. (2020). Dealing with Carbon Risk and the Cost of Debt: Evidence from the European Market. Ijfs 8 (4), 61. doi:10.3390/ijfs 8040061

Porter, M. E., and Linde, C. v. d. (1995). Toward a New Conception of the Environment-Competitiveness Relationship. J. Econ. Perspect. 9 (4), 97-118. doi:10.1257/jep.9.4.97

Porter, M. E. (1991). Towards a Dynamic Theory of Strategy. Strat. Mgmt. J. 12 (S2), 95-117. doi:10.1002/smj.4250121008

Qiao, L., and Fei, J. (2022). Government Subsidies, Enterprise Operating Efficiency, and "Stiff but Deathless" Zombie Firms. Econ. Model. 107, 105728. doi:10.1016/ j.econmod.2021.105728

Ramzan, M., Raza, S. A., Usman, M., Sharma, G. D., and Iqbal, H. A. (2021). Environmental Cost of Non-renewable Energy and Economic Progress: Do ICT and Financial Development Mitigate Some Burden? J. Clean. Prod. 333, 130066. doi:10.1016/j.jclepro.2021.130066

Rosenbaum, P. R., and Rubin, D. B. (1983). The Central Role of the Propensity Score in Observational Studies for Causal Effects. Biometrika 70 (1), 41-55. doi:10.1093/biomet/70.1.41

Saleem, H., Khan, M. B., and Shabbir, M. S. (2020). The Role of Financial Development, Energy Demand, and Technological Change in Environmental Sustainability Agenda: Evidence from Selected Asian Countries. Environ. Sci. Pollut. Res. 27 (5), 5266-5280. doi:10.1007/s11356019-07039-0

Schneider, T. E. (2008). Is There a Relation between the Cost of Debt and Environmental Performance? an Empirical Investigation of the US Pulp and Paper Industry, 1994-2005. Waterloo: UWSpace. Available at http://hdl.handle. net/10012/3962

Seo, D. W., and Han, S. H. (2021). Corruption and Corporate Cash Holdings. Emerging Markets Finance Trade, 1-15. doi:10.1080/1540496x.2021.1890022

Sharma, G. D., and Handa, M. (2021). Pathways for Advancing the Scholarship on Transformation towards a Sustainable and Equitable Community. Qual. Res. Organ. Manag. Int. J. 16, 425-434. doi:10.1108/qrom-11-2021-993

Sharma, G. D., Paul, J., Srivastava, M., Yadav, A., Mendy, J., Sarker, T., et al. (2021a). Neuroentrepreneurship: An Integrative Review and Research Agenda. Entrepreneurship Reg. Dev. 33 (9-10), 863-893. doi:10.1080/ 08985626.2021.1966106

Sharma, G. D., Rahman, M. M., Jain, M., and Chopra, R. (2021b). Nexus between Energy Consump-Tion, Information and Communications Technology, and Economic Growth: An Enquiry into Emerging Asian Countries. J. Public Aff. 21 (2), e2172. doi:10.1002/pa.2172

Sharma, G. D., Shah, M. I., Shahzad, U., Jain, M., and Chopra, R. (2021c). Exploring the Nexus between Agriculture and Greenhouse Gas Emissions in
BIMSTEC Region: The Role of Renewable Energy and Human Capital as Moderators. J. Environ. Manage. 297, 113316. doi:10.1016/ j.jenvman.2021.113316

Sharma, G. D., Talan, G., Bansal, S., and Jain, M. (2021d). Is There a Cost for Sustainable Investments: Evidence from Dynamic Conditional Correlation. J. Sustain. Finance Investment, 1-21. doi:10.1080/20430795.2021.1874215

Sharma, G. D., Tiwari, A. K., Jain, M., Yadav, A., and Srivastava, M. (2021e). COVID-19 and Environmental Concerns: A Rapid Review. Renew. Sustain. Energ. Rev. 148, 111239. doi:10.1016/j.rser.2021.111239

Sharma, G. D., Tiwari, A. K., Talan, G., and Jain, M. (2021f). Revisiting the Sustainable versus Conventional Investment Dilemma in COVID-19 Times. Energy Policy 156, 112467. doi:10.1016/j.enpol.2021.112467

Sharma, G. D., Sarker, T., Rao, A., Talan, G., and Jain, M. (2022). Revisiting Conventional and Green Finance Spillover in post-COVID World: Evidence from Robust Econometric Models. Glob. Finance J. 51, 100691. doi:10.1016/ j.gfj.2021.100691

Shen, J., Firth, M., and Poon, W. P. (2015). Bank Loan Supply and Corporate Capital Structure: Recent Evidence from China. SSRN Electron. J., 47. doi: $10.2139 /$ ssrn.2547860

Shi, X., and Xu, Z. (2018). Environmental Regulation and Firm Exports: Evidence from the Eleventh Five-Year Plan in China. J. Environ. Econ. Manage. 89, 187-200. doi:10.1016/j.jeem.2018.03.003

Spence, M. (1974). Market Signaling: Informational Transfer in Hiring and Related Screening Processes. cambridge: Harvard University Press.

Testa, F., Iraldo, F., and Frey, M. (2011). The Effect of Environmental Regulation on Firms' Competitive Performance: The Case of the Building \& Construction Sector in Some EU Regions. J. Environ. Manage. 92 (9), 2136-2144. doi:10.1016/j.jenvman.2011.03.039

Thompson, P., and Cowton, C. J. (2004). Bringing the Environment into Bank Lending: Implications for Environmental Reporting. Br. Account. Rev. 36 (2), 197-218. doi:10.1016/j.bar.2003.11.005

Villanthenkodath, M. A., Ansari, M. A., Shahbaz, M., and Vo, X. V. (2021). Do Tourism Development and Structural Change Promote Environmental Quality? Evidence from India. Environ. Dev. Sustainability, 1-32. doi:10.1007/s10668-021-01654-z

Wang, Y., Sun, X., and Guo, X. (2019). Environmental Regulation and Green Productivity Growth: Empirical Evidence on the Porter Hypothesis from OECD Industrial Sectors. Energy Policy 132, 611-619. doi:10.1016/ j.enpol.2019.06.016

Wen, H., Lee, C.-C., and Zhou, F. (2021). Green Credit Policy, Credit Allocation Efficiency and Upgrade of Energy-Intensive Enterprises. Energ. Econ. 94, 105099. doi:10.1016/j.eneco.2021.105099

Woods, N. D. (2006). Interstate Competition and Environmental Regulation: A Test of the Race-To-The-Bottom Thesis*. Social Sci. Q 87 (1), 174-189. doi:10.1111/j.0038-4941.2006.00375.x

Xiong, F., Zheng, Y., An, Z., and Xu, S. (2021). Does Internal Information Quality Impact Corporate Cash Holdings? Evidence from China. Account. Finance 61, 2151-2171. doi:10.1111/acfi.12657

Yan, Y., Shah, M. I., Sharma, G. D., Chopra, R., Fareed, Z., and Shahzad, U. (2021), Can Tourism Sustain Itself through the Pandemic: Nexus between Tourism, COVID-19 Cases and Air Quality Spread in the 'Pineapple State' Hawaii. Curr. Issues Tourism, 1-20. doi:10.1080/13683500.2021.1965553

Yikun, Z., Gul, A., Saleem, S., Shabbir, M. S., Bilal, K., and Abbasi, H. M. (2021). The Relationship between Renewable Energy Sources and Sustainable Economic Growth: Evidence from SAARC Countries. Environ. Sci. Pollut. Res. 28, 33390-33399. doi:10.1007/s11356-02112795-Z

Zhang, Y., Cui, J., and Lu, C. (2020). Does Environmental Regulation Affect Firm Exports? Evidence from Wastewater Discharge Standard in China. China Econ. Rev. 61, 101451. doi:10.1016/j.chieco.2020.101451

Zheng, S., and Kahn, M. E. (2017). A New Era of Pollution Progress in Urban China? J. Econ. Perspect. 31 (1), 71-92. doi:10.1257/jep.31.1.71

Zhu, L., Hao, Y., Lu, Z.-N., Wu, H., and Ran, Q. (2019). Do Economic Activities Cause Air Pollution? Evidence from China's Major Cities. Sustain. Cities Soc. 49, 101593. doi:10.1016/j.scs.2019.101593

Zhu, Y., Xie, J., Huang, F., and Cao, L. (2020). The Mediating Effect of Air Quality on the Association between Human Mobility and COVID-19 Infection in China. Environ. Res. 189, 109911. doi:10.1016/j.envres.2020.109911 
Zutshi, A., Mendy, J., Sharma, G. D., Thomas, A., and Sarker, T. (2021). From Challenges to Creativity: Enhancing SMEs' Resilience in the Context of COVID-19. Sustainability 13 (12), 6542. doi:10.3390/su13126542

Conflict of Interest: The authors declare that the research was conducted in the absence of any commercial or financial relationships that could be construed as a potential conflict of interest.

Publisher's Note: All claims expressed in this article are solely those of the authors and do not necessarily represent those of their affiliated organizations, or those of the publisher, the editors and the reviewers. Any product that may be evaluated in this article, or claim that may be made by its manufacturer, is not guaranteed or endorsed by the publisher.

Copyright $\odot 2022$ Zhang and Cheng. This is an open-access article distributed under the terms of the Creative Commons Attribution License (CC BY). The use, distribution or reproduction in other forums is permitted, provided the original author(s) and the copyright owner(s) are credited and that the original publication in this journal is cited, in accordance with accepted academic practice. No use, distribution or reproduction is permitted which does not comply with these terms. 